\title{
Plasma Prolactin Activity in Inappropriate Lactation
}

\author{
ISABEL A. FORSYTH, G. M. BESSER, C. R. W. EDWARDS, LYNN FRANCIS, RITA P. MYRES
}

\section{Materials and Methods}

\section{Summary}

Using a bioassay dependent on the development of a lactogenic response in rabbit mammary tissue cultured in vitro, prolactin distinct from immunoreactive growth hormone has been found in the plasma of patients of both sexes with inappropriate lactation with and without evidence of pituitary tumours. It has also been found in one patient with primary hypothyroidism and galactorrhoea, and in another during chlorpromazine therapy, but not in nine patients with gynaecomastia without galactorrhoea. Plasma prolactin levels were examined in seven patients during oral glucose tolerance tests: no change occurred in the four patients with pituitary tumours, but the levels were suppressed in the three patients with normal pituitary fossae. Prolactin appears to be a distinct pituitary hormone in man, as in animals, and also to be aetiologically related to states of inappropriate lactation.

\section{Introduction}

A number of syndromes of inappropriate lactation have been described but their aetiologies are poorly understood. While the mammary gland is a target for a number of hormones in the course of its development and function, in most mammals the pituitary polypeptide, prolactin, appears to be an essential constituent of the hormone complex required for lactation (Cowie, 1969). Research on lactation in man has been retarded by the lack of satisfactory assay methods for prolactin in blood, and until very recently the existence of human prolactin as a hormone distinct from human growth hormone (GH) has been a matter for controversy (Forsyth, 1969; Pasteels, 1969; Peake et al., 1969; Bewley and Li, 1970; Boot, 1970).

Now, however, methods are becoming available for the satisfactory separation of human prolactin based on recognition of its immunological similarity to ovine prolactin and lack of cross-reaction with human growth hormone (Guyda and Friesen, 1971). Moreover, a specific bioassay for lactogenic activity in plasma has been introduced in which the secretory response of rabbit or mouse mammary tissue cultured in vitro is used (Brumby and Forsyth, 1969; Forsyth, 1970; Frantz and Kleinberg, 1970), and this has provided fresh evidence for the presence of a human prolactin in plasma immunologically distinct from growth hormone (Forsyth, 1970; Frantz and Kleinberg, 1970; Forsyth and Myres, 1971). The present paper describes the use of this method to assay plasma from 20 patients with abnormal lactation and nine patients with simple gynaecomastia.

\footnotetext{
National Institute for Research in Dairying, Shinfield, Reading, Berks

ISABEL A. FORSYTH, M.A., D.PHIL., Senior Scientific Officer

LYNN FRANCIS, B.SC., Scientific Officer

RITA P. MYRES, B.sC., Experimental Officer

Medical Professorial Unit, St. Bartholomew's Hospital, London EC1A 7BE

G. M. BESSER, M.D., M.R.C.P., Senior Lecturer in Endocrinology

C. R. W. EDWARDS, M.B., M.R.C.P., Lecturer in Medicine
}

Prolactin Bioassay.-Explants of lobuloalveolar mammary tissue about $1 \mathrm{~mm}^{3}$ in size were removed from Dutch rabbits on the 11th day of pseudopregnancy induced with human chorionic gonadotrophin. The mammary tissue was cultured at $37^{\circ} \mathrm{C}$ in an atmosphere of $95 \%$ oxygen and $5 \%$ carbon dioxide on synthetic Medium 199 (B.D.H. Chemicals Ltd., Poole, Dorset). The medium contained insulin $(5 \mu \mathrm{g} / \mathrm{ml})$ and corticosterone $(1 \mu \mathrm{g} / \mathrm{ml})$. Since purified human prolactin was not available sheep prolactin (NIH-P-S6, $25 \mathrm{IU} / \mathrm{mg}$ ) was used as the standard. Plasma to be assayed was added to the medium at a concentration of $10 \%(\mathrm{v} / \mathrm{v})$ unless otherwise stated. The medium was changed after three days and culture terminated on the fifth day, when the explants were prepared for histological examination. The extent of survival (usually greater than $75 \%$ ) and the secretory responses were assessed "blind" without knowledge of the source or details of the plasma sample being studied. Each plasma was assayed using eight explants. An arbitrary grading system was used based on that of Barnawell (1965) and the mean response was compared with the responses to the standards. The results were analysed statistically with the Mann-Whitney non-parametric U test (Siegel, 1956). Full details of the method have been reported elsewhere (Forsyth and Myres, 1971).

Growth Hormone Radioimmunoassay.-The growth hormone preparation used as standard and for iodination was M.R.C. "Human Growth Hormone for radioiodination-69/46." Antibodies were produced in rabbits by using Imperial Cancer Research Fund GH batch 6 for immunization. The antiserum used in these assays was from rabbit 2, bled on 13 October 1967. The second antibody used for the separation of bound and free hormone was antirabbit globulin MR 66 (Wellcome Reagents Ltd.).

Plasma Samples and Patients.-Details of the 20 patients studied with abnormal lactation and the nine who had gynaecomastia without galactorrhoea are given in the Table. In addition plasma samples from 18 normally-lactating women who were between 4 and 10 days postpartum, one normal man, and 25 normal women were studied. Heparinized venous blood was collected for prolactin bioassay and the plasma was separated immediately by centrifugation and frozen until required for assay. The growth hormone levels were measured by radioimmunoassay. In seven patients plasma samples were obtained for prolactin assay after a $50-\mathrm{g}$ oral glucose load.

\section{Results}

\section{RESPONSE TO SHEEP PROLACTIN}

The relationship between added sheep prolactin and the mean lactogenic secretory grades in the bioassay is shown in the Chart. The minimum detectable amount of prolactin was approximately $10 \mathrm{ng}$, equivalent to $100 \mathrm{ng} / \mathrm{ml}$ in the original plasma added to the assay system at a concentration of $10 \%$, or $50 \mathrm{ng} / \mathrm{ml}$ when the plasma was assayed at $20 \%$. Human growth hormone showed activity approximately equivalent to that of sheep prolactin on a weight for weight basis. Other pituitary peptides did not show any lactogenic activity.

\section{PLASMA ASSAYS}

Normally-lactating Women.-Of the 18 women studied 12 
showed plasma lactogenic activity equivalent to between $\mathbf{5 0 0}$ and $2,000 \mathrm{ng} / \mathrm{ml}$ sheep prolactin. The growth hormone concentrations in the samples were between 7 and $<1 \mathrm{ng} / \mathrm{ml}$.

Abnormal Lactation. - Of the one man and 19 women studied 14 showed significant lactogenic activity in the plasma equivalent to between 50 and $>5,000 \mathrm{ng} / \mathrm{ml}$ prolactin. With the exception of the acromegalic patient (Case 3 ) this activity could not be accounted for by the plasma concentrations of immunoreactive growth hormone, which were less than $10 \%$ of the levels of growth hormone required for minimum lactogenic activity in the assay. Of the other 13 patients who had intrinsic plasma lactogenic activity not attributable to growth hormone seven had definite or probable evidence of pituitary tumours and two had partial hypopituitarism; the remainder had no other obvious pituitary abnormalities. One patient had primary hypothyroidism, amenorrhoea, and galactorrhoea, and in another the galactorrhoea appeared to be related to her chlorpromazine therapy.

Simple Gynaecomastia.-In one female and eight males with gynaecomastia without galactorrhoea there was no demonstrable plasma prolactin.

Control Plasmas.-Plasmas from the control patients without endocrine disease showed no lactogenic activity. The growth hormone levels varied between $<2$ and $11 \mathrm{ng} / \mathrm{ml}$.

\section{EFFECTS OF HYPERGLYCAEMIA}

Plasma prolactin levels were followed during oral glucose tolerance tests in seven patients. In two (Cases 12 and 13) who had no evidence of a pituitary tumour the fasting plasma prolactin levels were 1,000 and $750 \mathrm{ng} / \mathrm{ml}$, and fell significantly during the two and a half hours after glucose to 500 and $\mathbf{3 0 0}$ $\mathrm{ng} / \mathrm{ml}$ respectively. Similarly in another patient (Case 11) who had primary hypothyroidism the plasma prolactin was 2,000 $\mathrm{ng} / \mathrm{ml}$ before glucose and suppressed to $400 \mathrm{ng} / \mathrm{ml}$ during the glucose tolerance test. These changes could not be accounted

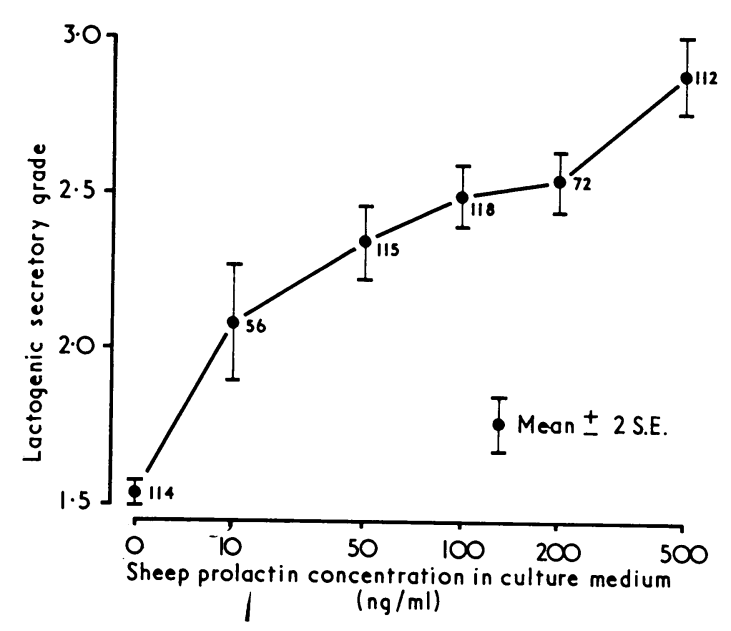

Dose-response relationship in the in-vitro rabbit mammary tissue prolactin assay. The numbers refer to total of explants studied at each dose level.

for by variations in plasma growth hormone. The remaining four patients, each of whom had radiological evidence of a pituitary tumour, showed no change in prolactin levels in the plasma during the glucose tolerance tests.

\section{Discussion}

The present report shows that lactogenic activity similar to that seen with purified animal prolactin can be found in the plasma of many patients with inappropriate lactation. While such lactogenic activity could be due to the raised growth hormone

Clinical Details and Plasma Prolactin Levels in 20 Patients with Galactorrhoea and in 9 with Simple Gynaecomastia

\begin{tabular}{|c|c|c|c|c|c|c|c|c|c|}
\hline Case No. & Sex & Age & Parity & $\begin{array}{l}\text { Interval since } \\
\text { Last Delivery } \\
\text { (Years) }\end{array}$ & $\begin{array}{c}\text { Duration of } \\
\text { Amenorrhoea } \\
\text { (Years) }\end{array}$ & $\begin{array}{c}\text { Duration of } \\
\text { Galactorrhoea } \\
\text { (Years) }\end{array}$ & $\underset{\text { Growth Hormone }}{\text { Plasma }}$ & $\underset{\text { Prolactin** }}{\text { Plasma } / \mathrm{ml})}$ & Comments $\dagger$ \\
\hline
\end{tabular}
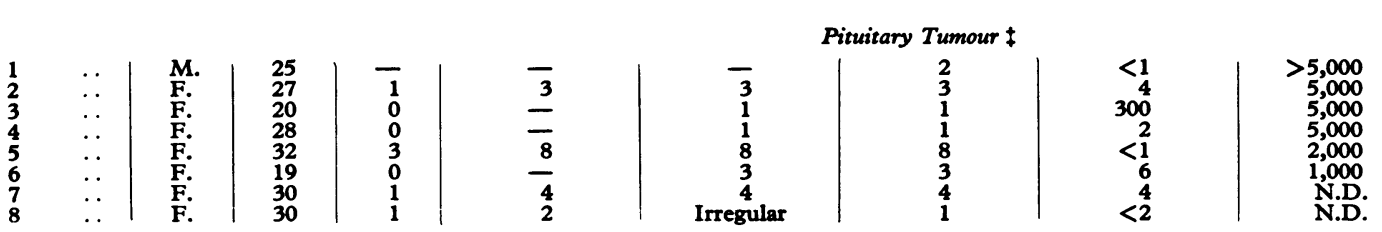

5,000
5,000
5,000
5,000
2,000
1,000
N.D.
N.D.

Acromegaly
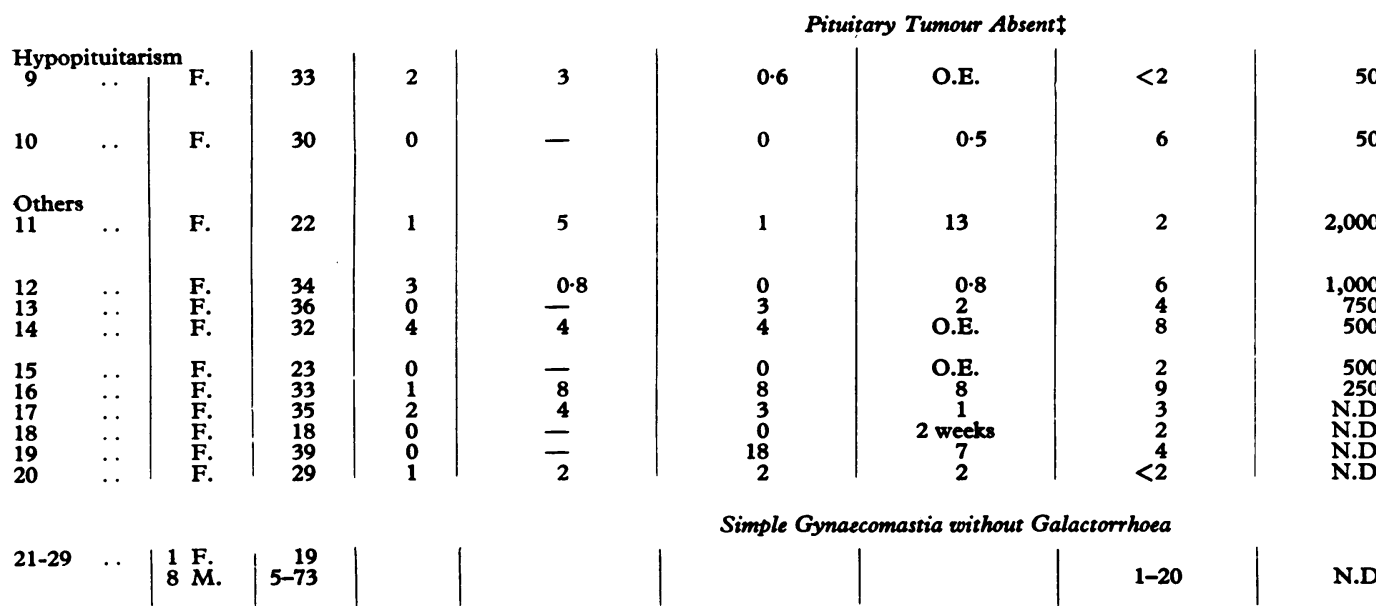

508
508

000

000
750
500
500
250
N.D.
N.D.
N.D.

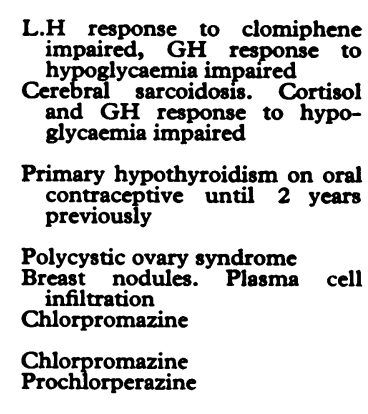

Simple Gynaecomastia without Galactorrhoea

* Estimated prolactin levels expressed as sheep prolactin equivalent.

+ Estimated prolactin levels expressed as sheep prolactin

Standard radiological criteria.

Plasma assayed at concentration of $20 \%$

N.D. = Not detectable-that is, $<100 \% \mathrm{ng} / \mathrm{ml}$ in plasma when assayed at $10 \%,<50 \mathrm{ng} / \mathrm{ml}$ when assayed at $20 \%$ concentration.

O.E. = Galactorrhoea discovered only on examination; duration uncertain. 
levels in the plasma of patients with severe acromegaly, this cannot be true for the other patients reported here who have been shown to have very low or undetectable immunoreactive growth hormone levels. Since the growth hormone levels could not account for this prolactin-like biological activity the evidence may be taken to indicate the presence of circulating prolactin distinct from growth hormone. While it is generally accepted that prolactin and growth hormone exist as separate pituitary polypeptides in animals, this has been previously doubted in man (Bewley and $\mathrm{Li}, 1970$ ). The studies presented here and those of Frantz and Kleinberg (1970) strongly suggest that prolactin does indeed exist in man.

For bioassay of plasma the method described in this paper represents a major improvement in convenience and sensitivity compared with the older pigeon-crop assay, enabling useful measurements to be made on unextracted samples. It is not, however, sensitive enough to detect basal levels of the hormone in normal non-lactating control subjects. Since the response of the rabbit mammary gland in vitro is measured by a histological endpoint, we feel that it should be regarded as only a semiquantitative assay, though Frantz and Kleinberg (1970) felt able to quantitate a similar method with the use of mouse mammary gland and reported an even greater sensitivity of response, detecting plasma levels of $15 \mathrm{ng}$ of sheep prolactin equivalent $/ \mathrm{ml}$.

Human growth hormone produces the same response as sheep prolactin in this assay. Growth hormone levels, however, can be measured direct by radioimmunoassay, and when these are low lactogenic activity can be ascribed to the content of prolactin. It is also possible to neutralize biological activity due to growth hormone by the incorporation of anti-growth-hormone antisera into the culture medium containing plasma from a lactating subject without loss of lactogenic activity (Frantz and Kleinberg, 1970; Forsyth and Myres, 1971). Current research directed towards the isolation of human prolactin (Guyda and Friesen, 1971) should result in the availability of a radioimmunoassay method shortly.

There are several clinical syndromes of inappropriate lactation accompanied by amenorrhoea in women-the Chiari-Frommel syndrome if the onset is postpartum, the Argonz-del Castillo syndrome if it is not, and the Forbes-Albright syndrome if a pituitary tumour is obvious. These are not distinct entities, however, since patients may progress from one syndrome to another and finally may develop acromegaly or Cushing's disease (Young et al., 1967; Mahesh et al., 1969). We have shown significant plasma prolactin activity in four out of six patients with the galactorrhoea-amenorrhoea-pituitary tumour syndrome and in half of the other patients with inappropriate lactation. One man with profuse galactorrhoea, slight gynaecomastia, impotence, and a pituitary tumour (Case 1) showed high circulating prolactin activity but no evidence of other endocrine disturbance. The remaining patients may well have had prolactin levels which were raised but below the current sensitivity of the assay.

Primary hypothyroidism is a rare cause of galactorrhoea and is reversible with thyroid replacement (Hennes et al., 1960; Bayliss and Van't Hoff, 1969). So far as we are aware Case 11 in this series represents the 14th case so far described and the first in which the galactorrhoea has been shown to be associated with high circulating prolactin levels. Further studies have shown that the prolactin concentration has fallen with thyroxine therapy. It is of interest that in the other cases the galactorrhoea developed postpartum, but in this patient the inappropriate lactation developed while she was taking an oestrogen-progestogen contraceptive.

Hypopituitarism may be associated with galactorrhoea and raised plasma prolactin levels (for example, Cases 9 and 10). In these cases presumably a lesion in the hypothalamus, or one affecting the pituitary stalk portal capillary system, interrupts the supply of hypothalamic hypophysiotropic factors to the pituitary (Meites, 1970). Thus prolactin inhibitory factor fails to reach the pituitary so that the normal tonic suppression of prolactin secretion is removed, resulting in high circulating prolactin levels and galactorrhoea. Similarly, the supply of releasing factors governing the other anterior pituitary hormones may be affected, giving rise to varying degrees of hypopituitarism. Phenothiazine administration is known to reduce hypothalamic prolactin inhibitory factor content in rats (Meites, 1970) and to produce galactorrhoea in man. In one out of three patients receiving such therapy we have shown high circulating prolactin levels.

One patient (Case 14), who presented with mammary hyperplasia with minimal galactorrhoea, but with recurrent painful breast nodules which showed plasma cell infiltration on histological examination, had high circulating prolactin activity in the plasma without evidence of other endocrine abnormalities. The role of prolactin in the development of breast tumours requires further evaluation.

Prolactin activity was present in two-thirds of the normallylactating postpartum women tested but was absent from all the control subjects studied. None of the patients with simple gynaecomastia without galactorrhoea showed evidence of abnormal prolactin activity in the plasma.

The mechanisms involved in controlling production and secretion of prolactin are unclear. It might be supposed that glucose could have a role by analogy with its effect on growth hormone secretion, and three patients without evidence of pituitary tumours showed definite suppression of their high prolactin levels during a glucose tolerance test, though the other patients who had pituitary tumours did not. This suggests that prolactin secretion in man may respond to hyperglycaemia in a similar fashion to growth hormone and that failure of suppression may indicate the presence of a pituitary tumour.

We may conclude that prolactin exists separately from growth hormone in patients with normal and inappropriate lactation and that it is probably of aetiological importance in galactorrhoea in men and women with or without pituitary tumours.

We are grateful to the following for sending plasma samples from patients under their care for assay and for permission to report details of their cases: Professor Russell Fraser, Professor E. T. G. Prunty, Professor A. P. M. Forrest, Professor P. J. Huntingford, Dr. M. Hartog, Dr. J. S. Jenkins, Dr. J. F. Hale, Dr. J. Cotes, and Dr. I. D. Cooke. We are also grateful to CIBA Laboratories, the Joint Research Board of St. Bartholomew's Hospital, and the Cancer Research Campaign for financial support. The sheep prolactin was a gift from the U.S. National Institutes of Health.

\section{References}

Barnawell, E. B. (1965). Fournal of Experimental Zoology, 160, 189.

Bayliss, P. F. C., and Van't Hoff, W. (1969). Lancet, 2, 1399.

Bewley, T. A., and Li, C. H. (1970). Science, 168, 1361.

Boot, L. M. (1970). International fournal of Cancer, 5, 167.

Brumby, H. I., and Forsyth, I. A. (1969). Fournal of Endocrinology, 43, 23.

Cowie, A. T. (1969). In Lactogenesis, ed. M. Reynolds and S. J. Folley, p. 157. Philadelphia, University of Pennsylvania Press.

Forsyth, I. A. (1969). In Lactogenesis, ed. M. Reynolds and S. J. Folley, p. 195. Philadelphia, University of Pennsylvania Press.

Forsyth, I. A. (1970). Fournal of Endocrinology, 46, 4.

Forsyth, I. A., and Myres, R. P. (1971). Fournal of Endocrinology. In press.

Forsyth, I. A., and Myres, R. P. (1971). Fournal of Endocrinology.

Frantz, A. G., and Kleinberg, D. L. (1970). Science, 170, 745. Research Communications, 42, 1068.

Hennes, A., Wajchenberg, B. L., and Ulhoa Cintra, A. B. (1960). Portugal Médico, 44, 693.

Mahesh, V. B., Pria, S. D., and Greenblatt, R. B. (1969). Journal of Clinical Endocrinology and Metabolism, 29, 978.

Meites, J. (editor) (1970). In Hypophysiotropic Hormones of the Hypothalamus, p. 261. Baltimore, Williams and Wilkins.

Pasteels, J.-L. (1969). In Lactogenesis, ed. M. Reynolds and S. J. Folley, p. 207. Philadelphia, University of Pennsylvania Press. Peake, G. T., McKeel, D. W., Jarett, L., and Daughaday, W. H. (1969).
fournal of Clinical Endocrinology and Metabolism, 29, 1383.

Siegel, S. (1956). In Non Parametric Statistics for the Behavioural Sciences, p. 116. New York, McGraw-Hill.

Young, R. L., Bradley, E. M., Goldzieher, J. W., Myers, P. W., and Lecoco F. R. (1967). Fournal of Clinical Endocrinology and Metabolism, 27, 461 . 